\title{
Underestimating the Value of an Intervention: The Case for Including Productivity in Value Assessments and Formulary Design
}

\author{
Taruja Karmarkar, PhD, MHS; Jennifer S. Graff, PharmD; and Kimberly Westrich, MA
}

\begin{abstract}
BACKGROUND: Value assessment reports are increasingly being considered in health care coverage decisions. The inputs included and analytic methodologies underlying these reports should include all components of value.

OBJECTIVE: To determine whether and how productivity was included in a value assessment, compare the incremental cost per quality-adjusted lifeyear (cost/QALY) estimates with and without productivity, assess if inclusion of productivity changed the value category and estimate the direction and magnitude of change.
\end{abstract}

METHODS: We reviewed pharmaceutical value assessment reports published between March 2017 and July 2019 by the Institute for Clinical and Economic Review (ICER) to determine whether productivity was included and how it was reported (i.e., co-base case or scenario analysis). Within each report, we identified unique treatment comparisons for which modelers estimated an incremental cost/QALY. We categorized the incremental cost/QALY estimates using ICER's willingness-to-pay (WTP) categories and assessed if inclusion of productivity changed the value category (i.e., $<\$ 50,000 / Q A L Y)$. For reports that included 2 numerical estimates, we assessed the direction and magnitude of change when productivity was included.

RESULTS: Of the 19 reports that evaluated pharmaceutical treatments, $18(94.7 \%)$ included productivity. Two reports $(11.1 \%)$ incorporated productivity in a co-base case analysis, and 16 included productivity in a scenario analysis. Across these 18 reports, there were 75 unique comparisons of pharmaceutical interventions. Across the 75 comparisons, 4 (5.3\%), $3(4.0 \%), 8(10.6 \%)$, and $1(1.3 \%)$ of the coverage decisions would change at the $\$ 50,000 /$ QALY, $\$ 100,000 /$ QALY, $\$ 150,000 /$ QALY, and \$500,000/QALY threshold, respectively. Sixty comparisons included 2 numerical cost/QALY estimates. The magnitude of change in the cost/QALY, after including productivity, ranged from $-80.1 \%$ to $6.8 \%$. The estimated value increased for $54(72 \%)$, decreased for $5(6.6 \%)$, and did not change for $1(1.7 \%)$ of the comparisons.

CONCLUSIONS: Value assessment should capture the range of costs and benefits of an intervention. The exclusion of productivity costs can alter, often underestimating, the assessment of value. This may affect coverage decisions-inclusion or exclusion from the insurance benefit-based on these assessments. Value assessment reports intended to be used for health care decision making should include productivity and elevate its visibility by using base-case analyses rather than scenario analyses.

J Manag Care Spec Pharm. 2020;26(5):652-61

Copyright $\odot 2020$, Academy of Managed Care Pharmacy. All rights reserved.

\section{What is already known about this subject}

Work productivity is an important patient-centered component of value that should be included in value assessments of health care interventions.

Experts recommend that value assessments of health care interventions, based on cost-effectiveness analyses, should be conducted using a societal perspective, alongside the health care sector perspective, to capture the full range of costs and benefits that can drive value.

\section{What this study adds}

Since March 2017, 18 of 19 (94.7\%) pharmaceutical value assessment reports from the Institute for Clinical and Economic Review included productivity costs in the report, but only 2 (11.1\%) included productivity in a primary (co-base case) analysis.

Including productivity generally increased the estimated value of a treatment (decreased cost/QALY estimates) but varied in magnitude $(-80.1 \%$ to $6.8 \%$ ) and by disease type (orphan vs. nonorphan disease). The value category changed in 2 of 9 (22.2\%) comparisons for treatments for orphan diseases and in 14 of 66 (21.2\%) comparisons for treatments for nonorphan disease populations.

To support appropriate patient access to treatments, it is important to include key factors such as productivity in value assessments that may be used by payers to inform coverage decisions in the United States.

A $\mathrm{s}$ the United States moves toward a value-based payment health care system, there is growing discussion around how to define and measure value. In response to this measurement need, several value assessment frameworks have been developed each with different methods. ${ }^{1}$ These frameworks now have real-world implications for patients, and payers, such as CVS, are beginning to use these value assessment frameworks to make coverage decisions..$^{2,3}$ How might these decisions be affected by the exclusion (or inclusion) of a key component of value from the assessment? ${ }^{3}$

A key component of value often overlooked is productivity. The onset of a new health condition, or the deterioration of an individual's health status, can affect an individual's performance in the workforce or result in inefficient work or missed days from work due to ill-health. Medical treatments can have a positive or negative effect on an individual's health status 
and hence affect productivity in a positive or negative manner. Employers often are already providing health insurance coverage for the employee, and expending additional resources to reallocate staff or to train new hires to account for an ill individual's time away from work increases health-related costs for employers. ${ }^{4}$ Therefore, any loss in productivity due to health comes at a cost to both the individual and his or her employer. Given this effect, assessments of the value of health interventions should include productivity.

One method to compare the value of a health intervention with treatment alternatives is cost-effectiveness analysis (CEA), which quantifies the result as an incremental cost-effectiveness ratio presented as dollars per quality-adjusted life-year (cost/QALY). The lower the incremental cost/QALY, the lower the cost to achieve an additional unit of benefit. ${ }^{5}$ To ensure the benefits and costs beyond the health care system are appropriately assessed, experts in health economics and policy have urged the inclusion of productivity in value assessment. The Second Panel on Cost-Effectiveness in Health \& Medicine (Second Panel), a group of experts from academia, health care administration, and government who set the standards for reporting cost-effectiveness studies, recommended value assessments include a societal perspective, as a co-base case, which incorporates the effect on nonhealth sectors including productivity, educational achievement, housing, social services, and criminal justice. ${ }^{6,7}$ Other analyses have pointed out that exclusion of such measures can underestimate the value of an intervention. ${ }^{8}$

Underestimation of value can have important implications on the decisions made by policymakers and payers. These incremental cost/QALY figures are sometimes used to identify allocation of resources toward particular interventions and away from others through willingness-to-pay (WTP) thresholds. Although there is controversy around the use of these thresholds in the United States, the Institute for Clinical and Economic Review (ICER) uses a range of thresholds to make CEA-based judgments of value in its assessments: $\$ 50,000, \$ 100,000$, and $\$ 150,000 /$ QALY for most treatments and $\$ 500,000 / \mathrm{QALY}$ for orphan drugs. ${ }^{9,10}$ In the United States, CVS has piloted a benefit design that allows formulary exclusions for treatments exceeding the \$100,000/QALY threshold. ${ }^{11}$ New York State's Drug Utilization Review Board recommended a supplemental rebate for lumacaftor/ivacaftor (Orkambi, Vertex), a cystic fibrosis drug, based on ICER's \$150,000/QALY threshold. ${ }^{12}$ Although these plans have been made public, other payers have not announced the use of a specific threshold. Survey research indicates that the percentage of U.S. payers following an ICER cost-effectiveness threshold, throughout the coverage and decision-making process, is growing. ${ }^{13,14}$

Given the growing use of value assessments in payer decisions, we illustrate how, when productivity is included in value assessments, it can lead to different value categorizations and decisions, which can subsequently affect patient access to care.

\section{Methods}

To study the effect of including productivity on an assessment of value, we identified and reviewed all ICER value assessment reports published between March 2017 and July 2019 that focused on pharmaceutical treatments. This time period was chosen because ICER revised its assessment framework and began to quantitatively include work productivity in March 2017. Among the many existing value frameworks, ICER reports were chosen because the 2017 methodologic update provided a large volume of reports suitable for this analysis. ${ }^{15}$ One author extracted the data from ICER reports for this study (TK). Two authors reviewed the data before analysis (JG and KW).

Within each report, we identified unique treatment comparisons for which modelers estimated an incremental cost/QALY and noted how it was reported (e.g., co-base case or scenario analysis; see Appendix, available in online article). A co-base case, from the societal perspective, increases the consistency and comparability of evaluations across different patient populations and diseases., ${ }^{7,16}$ If the societal perspective is only taken in the scenario analysis, which was not consistently conducted, end-users may not capture the full effect of an intervention.

We then categorized the incremental cost/QALY estimates into categories created using ICER's WTP thresholds for orphan and nonorphan diseases:

- dominant: less costly, more effective

- $<\$ 50,000 / \mathrm{QALY}$

- $\$ 50,000 / \mathrm{QALY}$ to $<\$ 100,000 / \mathrm{QALY}$

- $\$ 100,000 /$ QALY to $<\$ 150,000 /$ QALY

- $\$ 150,000 /$ QALY to $<\$ 500,000 /$ QALY

- $>\$ 500,000 /$ QALY (used only for ultrarare disease)

- dominated: more costly, less effective

We then assessed if the inclusion of productivity costs changed the value category. Finally, for those reports in which 2 numerical estimates of cost/QALY (i.e., incremental cost/QALY values that were not considered dominant or dominated) were provided, 1 with and 1 without productivity, we assessed the direction and estimated the magnitude of change.

\section{Results}

Of the 19 ICER reports evaluating pharmaceutical interventions published since March 2017, 18 (94.7\%) provided an alternative perspective in which work productivity was considered. One report, regarding therapies for ovarian cancer, did not include work productivity. Two of the 18 reports (11.1\%) for childhood blindness and amyloidosis-were evaluated under ICER's modified framework for ultrarare diseases, which includes the calculation of a cost/QALY with work productivity as part of a co-base case analysis. The remaining 16 (88.8\%) reports included work productivity as a scenario analysis. 


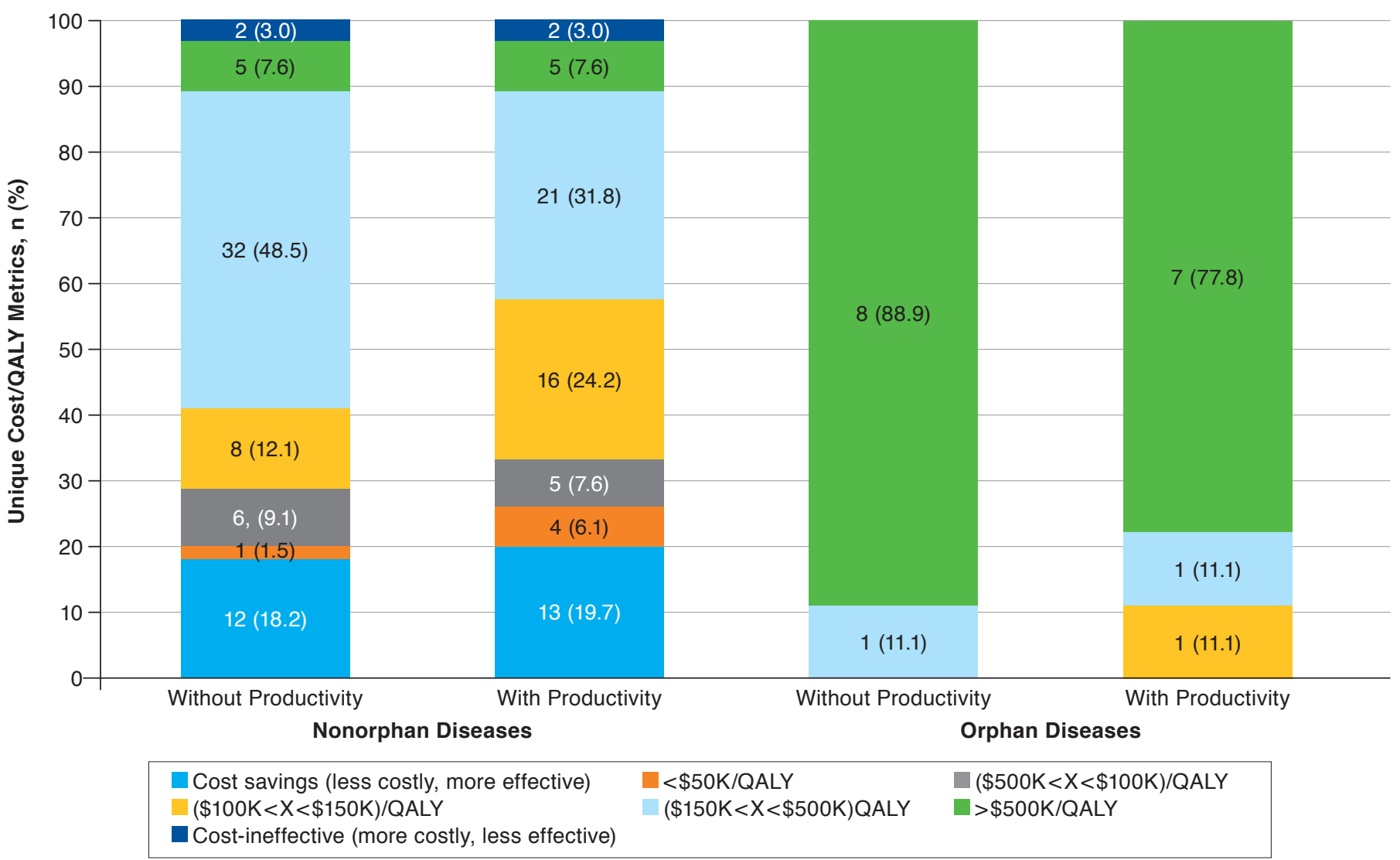

QALY= quality-adjusted life-years; WTP = willingness-to-pay

The inclusion of productivity changed the categorization of value using ICER's WTP threshold categories for both orphan and nonorphan diseases (Figure 1). Within the 18 reports, we found 75 unique comparisons of pharmaceutical interventions. With the inclusion of productivity, the distribution of cost/QALY estimates shifted to lower threshold (higher value) categories for 16 of the 75 (21.3\%) unique treatment comparisons. At the lower and upper bounds of the distribution for nonorphan diseases, little effect was found when excluding or including productivity costs on the dominant (18.18\% vs. $19.7 \%$, respectively) and dominated (3.03\% vs. 3.03\%) WTP categories. We saw a small increase in the number of interventions that fell between cost savings and the \$50,000/QALY category $(1.5 \%$ vs. $6.1 \%)$ and a small decrease in the number of interventions that fell between \$50,000/QALY and $\$ 100,000 /$ QALY (9.1\% vs. $7.6 \%$ ) once productivity was included. Using the $\$ 150,000 /$ QALY threshold, $40.9 \%$ of cost/QALY estimates fell below the $\$ 150,000 /$ QALY threshold when productivity was not included but increased to $57.58 \%$ of all cost/QALY estimates after productivity costs were incorporated.
For orphan diseases, in which value assessments include the $\$ 500,000 / \mathrm{QALY}$ threshold in addition to the $\$ 50,000 / \mathrm{QALY}-$ $\$ 150,000 /$ QALY thresholds, we found fewer changes with the majority of the cost/QALY estimates remaining above the $\$ 500,000 /$ QALY threshold (88.89\% vs. $77.78 \%$ ).

The value category changed in 2 of 9 (22.2\%) comparisons for treatments for orphan diseases and in 14 of 66 (21.2\%) comparisons for treatments for nonorphan disease populations.

Across the 75 comparisons, 4 (5.3\%), 3 (4\%), 8 (10.6\%), and $1(1.3 \%)$ of the coverage decisions would change at the $\$ 50,000 /$ QALY, \$100,000/QALY, \$150,000/QALY, and \$500,000/QALY threshold, respectively.

Although the inclusion of productivity generally improved the assessment of value, this was not uniform across all treatment comparisons. We calculated a percentage difference (Figure 2) among the 60 comparisons in which 2 numerical cost/QALY estimates were provided (1 with and 1 without productivity). For 54 (90.0\%) of the 60 comparisons, inclusion of productivity costs improved the estimated value, decreasing 
Underestimating the Value of an Intervention: The Case for Including Productivity in Value Assessments and Formulary Design

FIGURE 2 Change (\%) in Cost/QALY with Inclusion of Productivity Costs

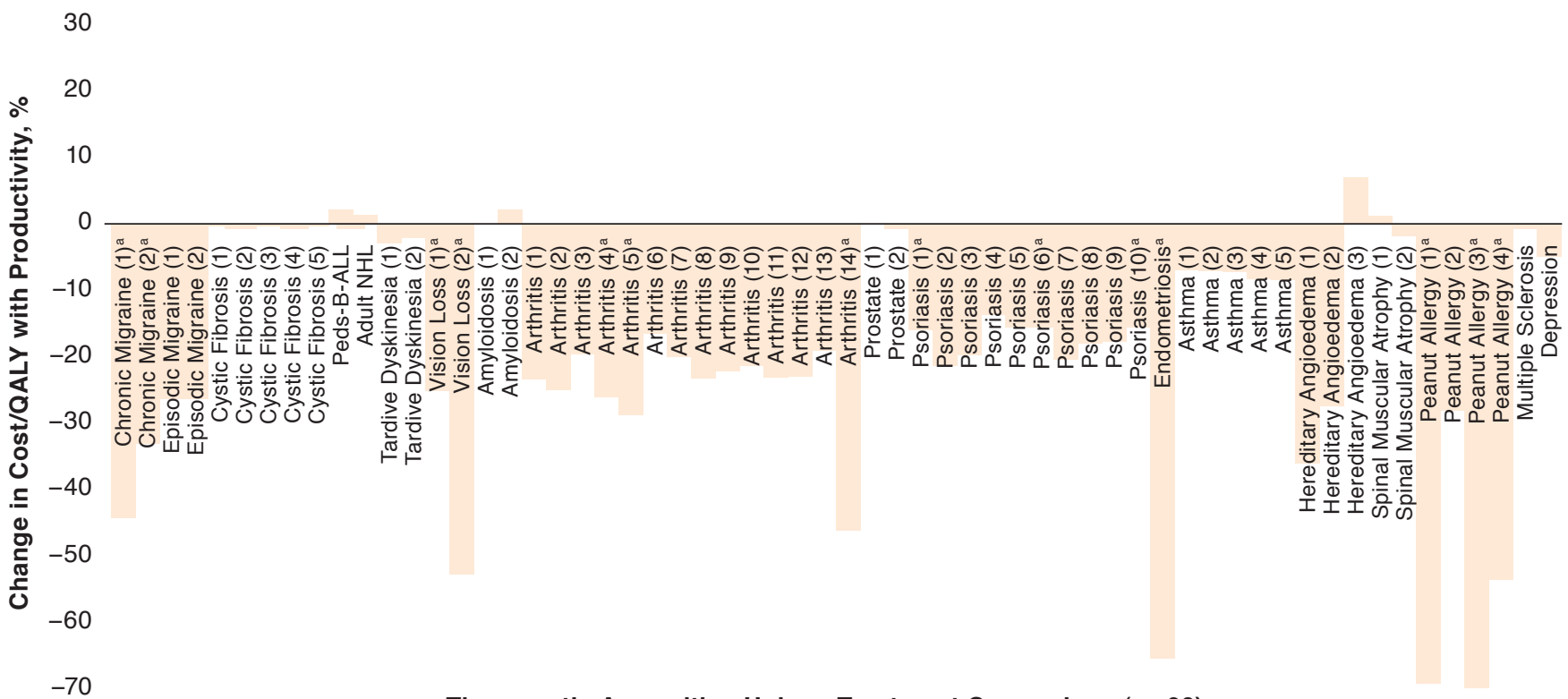

Therapeutic Area with a Unique Treatment Comparison $(n=60)$

Note: This graph includes unique comparisons in which there were 2 numerical cost/QALY estimates used to calculate a percentage change ( $n=60)$. Multiple treatment comparisons within a single report are indicated using a number. For example, there were 2 unique treatment comparisons for chronic migraine (erenumab vs. no preventive treatment; fremanezumab vs. no preventive treatment).

a Indicates a comparison in which the percentage change in cost/QALY led to a change in WTP threshold categorization.

NHL=non-Hodgkin leukemia; QALY=quality-adjusted life-year; WTP= willingness-to-pay.

the incremental cost/QALY by $-0.5 \%$ to $-80.1 \%$. For 5 (8.3\%) comparisons, the incremental cost/QALY increased by $0.1 \%$ to $6.8 \%$ representing a decrease in value. For 1 (1.7\%) comparison, there was no change.

For 16 of these 60 (26.7\%) comparisons, including productivity changed the ICER value category. These changes occurred across various therapeutic areas-chronic migraine, vision loss, arthritis, psoriasis, endometriosis, and peanut allergies (see footnoted conditions in Figure 2).

\section{Discussion}

The effects of poor health are felt beyond the health care sector. ${ }^{17-19}$ Our review highlights that work productivity can and does have an effect on the assessment of value. Although the magnitude of change varied widely, most of the comparisons in our analysis saw an improvement in value-or a reduction in cost/QALY - when productivity was included. With the recent focus on value assessment to inform formulary coverage decisions, this can have a tangible effect on patient access.

Although several nonhealth care sectors can be affected by health interventions, this study focused on productivity costs given the data most consistently and systematically provided in ICER reports. By focusing solely on productivity costs, we were able to include a larger number of comparisons as part of our analytic sample and ensure an appropriate comparison between cost/QALY estimates. The decision to formally include productivity in an analysis from the societal perspective was a prominent change as part of the methodologic revisions to ICER's framework and provided the opportunity to analyze this component of value. ${ }^{14,15}$

Incorporating the costs and benefits of work productivity has challenges. For example, the report on ovarian cancer did not include any analyses from a societal perspective. The report states that "given the typically advanced age [of] and severity of disease" in ovarian cancer patients, there was "limited evidence on indirect costs, employment levels, and time missed at work." ${ }^{20}$ However, for some women, as noted in the ICER report, ovarian cancer can occur in their 30s and 40s when they are "immersed in careers, civic engagement, or parenting." ${ }^{20}$ Limited evidence available to estimate the productivity costs is a pervasive issue. Several existing instruments and databases already collect the type of data necessary to calculate productivity costs; however, additional efforts are necessary to fill gaps in data. ${ }^{21,22}$ Future efforts to identify therapeutic areas in which productivity has the greatest effect could inform targeted data collection efforts. Although an important 
component of CEA methodology, experts have cautioned about the potential drawbacks of estimating and including productivity. Using the WTP approach could result in double counting of the value of productivity in the incremental cost/QALY estimate-in the estimation of costs in the numerator and in the estimation of utility, or the quality component of the QALY, in the denominator. ${ }^{23}$ Additionally, whereas most models, including those developed by ICER, use the human capital approach to value productivity, the friction cost approach may provide a more accurate estimation of net productivity loss when a new, healthy employee is hired in place of an employee in ill-health. ${ }^{23}$

Although health economists agree productivity costs should be included as a co-base case in value assessments, how these costs are presented in the final reports matters. Some modelers include productivity in a co-base case analysis from the societal perspective, consistent with the recommendations of the Second Panel. For example, ICER's ultrarare disease framework uses this approach. Models by the Innovation and Value Initiative also use a broad societal approach. ${ }^{24}$ However, in most of the reports we reviewed, ICER included productivity as a scenario analysis, which is not included in report summaries. This limits the visibility of productivity estimates to end-users, potentially excluding important costs and benefits from the decision-making process for payers.

The effect of changes in an individual's work productivity extend beyond the individual. Employers face the costs of replacing a sick employee and experience the business effect of lost work time due to an employee in ill-health. ${ }^{25}$ Previous research has quantified this potential productivity loss borne by employers when employees experience a range of health conditions. ${ }^{26}$ In the U.S. health care system, employers also play a significant role in paying for health care benefits and an increasing role in employee wellness. ${ }^{25}$ If they face these costs for their employees and health plans are making benefit design decisions using value assessments, it follows employers would want productivity to be factored into those assessments. ${ }^{27}$

This review demonstrates that leaving productivity out of assessments can underestimate the value of a therapeutic intervention. For payers using ICER's WTP thresholds as a criterion for determining coverage, decisions on what to cover and for whom could change, subsequently affecting patient access to therapies.

\section{Limitations}

Our review of value assessment reports has some limitations worth noting. First, we were limited to the conditions and comparisons covered in the existing reports. Inclusion of productivity in specific clinical conditions and comparisons (i.e., migraines or vision loss) changed the value of the intervention but may not hold true in other clinical contexts.
Second, our review and conclusions were constrained by the data and evidence used in the reports to estimate productivity. Using different data sources or studies may yield different cost/ QALY estimates. Although we note the risks of underestimating value using cost/QALY estimates, the overestimation of value may lead to an alternate allocation of resources that may similarly affect coverage. Payers have finite resources with which to provide coverage and an accurate estimate of value is important to ensure the appropriate allocation of those resources.

Third, ICER's value assessment reports are specific to the context of the U.S. health care system and may not be generalizable to international settings. Fourth, the value assessment reports in this review focus on pharmaceutical products. Understanding the value of various health interventions is beneficial to a broad audience; however, the application of value assessments in the United States has largely focused on pharmaceutical products.

Finally, in reports for select therapeutic areas, such as opioid use disorder, vision loss, and amyloidosis, modelers incorporated nonhealth care factors in addition to productivity in the analysis from the societal perspective. Although we cannot isolate the effect of productivity on the value estimate in these cases, it emphasizes the importance of measuring value holistically and the effects of health or ill-health beyond clinical outcomes.

\section{Conclusions}

We found productivity costs were often included in an alternative, rather than primary, assessment of value in cost-effectiveness analysis-based value assessment reports. Overall, when included, productivity costs and benefits generally increased the estimated value of an intervention although the magnitude varied widely. Although the formal use of value thresholds in benefit design is in its early stages and effect on coverage decisions may vary with choice of threshold, the potential role of productivity in assigning value to pharmaceutical therapies is important.

Payers, facing the reality of finite resources, are increasingly looking to quantitative metrics found in value assessment reports to help inform benefit design. Because the inclusion of productivity, valued by both patients and employers, might change the determination of value, it is critical that value assessment reports intended to be used for health care decision-making both include productivity and ensure its visibility by using co-base case analysis rather than scenario analysis. Health plans using assessments that exclude productivity risk inappropriate restrictions on patient access to treatments that have been undervalued. To support value-based access to treatments, it is important to include key factors such as productivity in value assessments that may be used by payers to inform coverage decision. 


\section{Authors}

TARUJA KARMARKAR, PhD, MHS, Postdoctoral Fellow; JENNIFER S. GRAFF, PharmD, Comparative Effectiveness Research; and KIMBERLY WESTRICH, MA, Health Services Research, National Pharmaceutical Council, Washington, DC.

AUTHOR CORRESPONDENCE: Taruja Karmarkar, PhD, MHS, National Pharmaceutical Council, 1717 Pennsylvania Ave., Washington, DC 20006. Tel.: 202.827.2090;

E-mail: tkarmarkar@npcnow.org.

\section{DISCLOSURES}

This study was funded by the National Pharmaceutical Council. Karmarkar is currently a postdoctoral fellow at the National Pharmaceutical Council. Graff and Westrich are employees of the National Pharmaceutical Council, which provides unrestricted research grants to value assessment bodies including ICER and IVI.

\section{REFERENCES}

1. Dubois RW, Westrich K. As value assessment frameworks evolve, are they finally ready for prime time? Value Health. 2019;22(9):977-80.

2. Cohen J. ICER's growing impact on drug pricing and reimbursement. Forbes. April 17, 2019. Available at: https://www.forbes.com/sites/ joshuacohen/2019/04/17/icers-growing-impact-on-drug-pricing-andreimbursement/\#6eeee3lc6b53. Accessed April 2, 2020.

3. Happe L. Announcing a new article series: perspectives on value. J Manag Care Spec Pharm. 2019;25(1):8-9. Available at: https://www.jmcp.org/doi/ full/10.18553/jmcp.2019.25.1.008.

4. Kaiser Family Foundation. State health fact: employer-sponsored coverage rates for the nonelderly by age. 2017. Available at: https://www.kff.org/other/ state-indicator/rate-by-age-2/?currentTimeframe $=0$ \&sortModel=\%7B\%22colId \%22:\%22Location\%22,\%22sort\%22:\%22asc\%22\%7D. Accessed April 3, 2020.

5. Sanders GD, Maciejewski ML, Basu A. Overview of cost-effectiveness analysis. JAMA. 321(14):1400-02.

6. Sanders GD, Neumann PJ, Basu A, et al. Recommendations for conduct, methodological practices, and reporting of cost-effectiveness analyses: Second Panel on Cost-Effectiveness in Health and Medicine. JAMA. 2016;316(10):1093-103.

7. Neumann PJ, Sanders GD, Russell LB, Siegel JE, Ganiats TG, eds. CostEffectiveness in Health and Medicine. 2nd ed. New York: Oxford University Press; 2017.

8. Neumann PJ, Kamal-Bahl S. Should value frameworks take a 'societal perspective'? Heath Affairs Blog. September 6, 2017. Available at: https:// www.healthaffairs.org/do/10.1377/hblog20170906.061833/full/. Accessed April 3, 2020.

9. Institute for Clinical and Economic Review. ICER value assessment framework. 2020. Available at: https://icer-review.org/methodology/icers-methods/ icer-value-assessment-framework-2/. Accessed April 3, 2020.

10. Institute for Clinical and Economic Review. Modifications to the ICER value assessment framework for treatments for ultra-rare diseases. November 2017. Available at: https://icer-review.org/wp-content/uploads/ 2017/11/ICER-Adaptations-of-Value-Framework-for-Rare-Diseases.pdf. Accessed April 3, 2020.
11. Dubois RW. CVS to restrict patient access using cost-effectiveness: too much, too soon. Health Affairs Blog. September 17, 2018. Available at: https://www.healthaffairs.org/do/10.1377/hblog20180913.889578/full/. Accessed April 3, 2020.

12. Niedzwiadek N, Goldberg D. State board recommends supplemental rebate for cystic fibrosis drug. Politico. April 26, 2018. Available at: https:// www.politico.com/states/new-york/albany/story/2018/04/26/state-boardrecommends-supplemental-rebate-for-cystic-fibrosis-drug-387847. Accessed April 3, 2020.

13. First Report Managed Care. How payers are using ICER reports. November 2018. Available at: https://www.managedhealthcareconnect.com/ article/how-payers-are-using-icer-reports. Accessed April 3, 2020.

14. ICON Plc. Payers report that ICER analyses increasingly guide U.S. price negotiations. November 15, 2019. Available at: https://www.iconplc com/insights/blog/2019/11/15/payers-report-that-icer-analyses-increasinglyguide-us-price-negotiations/. Accessed April 3, 2020.

15. Institute for Clinical and Economic Review. Overview of the ICER value assessment framework and update for 2017-2019. May 8, 2018. Available at: https://icer-review.org/wp-content/uploads/2017/06/ICER-value-assessmentframework-Updated-050818.pdf. Accessed April 3, 2020.

16. Institute for Clinical and Economic Review. ICER's reference case for economic evaluations: principles and rationale. July 16, 2018. Available at: http://icer-review.org/wp-content/uploads/2018/07/ICER_Reference_Case_ July-2018.pdf. Accessed April 3, 2020.

17. Chen AJ, Goldman DP. Productivity benefits of medical care: evidence from US-based randomized clinical trials. Value Health. 2018;21(8): 905-10.

18. Krol M, Papenburg J, Swan Tan S, Brouwer W, Hakkaart L. A noticeable difference? Productivity costs related to paid and unpaid work in economic evaluations on expensive drugs. Eur J Health Econ. 2016;17(4):391-402.

19. Fu AZ, Qiu Y, Radican L, Wells BJ. Health care and productivity costs associated with diabetic patients with macrovascular comorbid conditions. Diabetes Care. 2009;32(12):2187-92.

20. Institute for Clinical and Economic Review. Poly ADP-ribose polymerase (PARP) inhibitors for ovarian cancer: effectiveness and value. September 28, 2017. Available at: https://icer-review.org/wp-content/uploads/2017/02/ MWCEPAC_OVARIAN_FINAL_EVIDENCE_REPORT_10112017-1.pdf. April 3, 2020.

21. Reilly MC, Gooch KL, Wong RL, Kupper H, van der Heijde D. Validity, reliability and responsiveness of the Work Productivity and Activity Impairment Questionnaire in ankylosing spondylitis. Rheumatology. 2010;49(4):812-19.

22. Agency for Healthcare Research and Quality. Medical Expenditure Panel Survey. 2019. Available at: https://meps.ahrq.gov/mepsweb. Accessed April 3, 2020.

23. Neumann PJ, Kim DD Trikalinos TA, et al. Future directions for cost-effectiveness analyses in health and medicine. Med Decis Making. 2018;38(7):767-77.

24. Linthicum MT, Bright J, Shafrin J. Open-source tools for value assessment: a promising approach. J Clin Pathways. 2018;4(5):37-39.

25. Parry T, Sherman B. Workforce health-the transformation from cost to outcomes to business performance. Benefits Q. 2015;31(1):32-38.

26. Mitchell RJ, Bates P. Measuring health-related productivity loss. Popul Health Manag. 2011;14(2):93-98.

27. Japsen B. Poor worker health costs U.S. employers half trillion dollars a year. Forbes. November 15, 2018. Available at: https://www.forbes.com/ sites/brucejapsen/2018/11/15/poor-worker-health-costs-u-s-employers-halftrillion-dollars-a-year/\#5b8f6da6d3be. Accessed April 3, 2020. 


\section{APPENDIX List of Treatment Comparisons Across All Reports}

\begin{tabular}{|c|c|c|c|c|c|c|c|c|c|c|}
\hline$\#$ & $\begin{array}{c}\text { Disease/ } \\
\text { Condition } \\
\end{array}$ & $\begin{array}{c}\text { Drug/ } \\
\text { Intervention }\end{array}$ & Comparator & $\begin{array}{c}\text { Cost/QALY } \\
\text { (without } \\
\text { productivity) }\end{array}$ & $\begin{array}{l}\text { Cost/QALY } \\
\text { (with } \\
\text { productivity) }\end{array}$ & $\begin{array}{l}\text { Changes } \\
\text { ICER } \\
\text { Threshold } \\
\text { Category? } \\
\end{array}$ & $\begin{array}{c}\% \\
\text { Change } \\
\end{array}$ & $\begin{array}{c}\text { Base Case } \\
\text { vs. } \\
\text { Scenario } \\
\end{array}$ & $\begin{array}{c}\text { Model } \\
\text { Perspective }\end{array}$ & $\begin{array}{c}\text { ICER Thresholds } \\
\text { for Comparison }\end{array}$ \\
\hline 1 & $\begin{array}{l}\text { Chronic } \\
\text { Migraine }\end{array}$ & erenumab & $\begin{array}{l}\text { no preventive } \\
\text { treatment }\end{array}$ & $\$ 90,000$ & $\$ 50,000$ & $\mathrm{Y}$ & $-44.40 \%$ & Scenario & $\begin{array}{l}\text { Health } \\
\text { system }\end{array}$ & $\begin{array}{l}\$ 50,000 / \text { QALY, } \\
\$ 100,000 / \text { QALY } \\
\text { and } \$ 150,000 / \\
\text { QALY }\end{array}$ \\
\hline 2 & $\begin{array}{l}\text { Chronic } \\
\text { Migraine }\end{array}$ & fremanezumab & $\begin{array}{l}\text { no preventive } \\
\text { treatment }\end{array}$ & $\$ 120,000$ & $\$ 80,000$ & $\mathrm{Y}$ & $-33.30 \%$ & Scenario & $\begin{array}{l}\text { Health } \\
\text { system }\end{array}$ & \\
\hline 3 & \begin{tabular}{|l|} 
Episodic \\
Migraine
\end{tabular} & erenumab & $\begin{array}{l}\text { no preventive } \\
\text { treatment }\end{array}$ & $\$ 150,000$ & $\$ 110,000$ & $\mathrm{~N}$ & $-26.70 \%$ & Scenario & $\begin{array}{l}\text { Health } \\
\text { system }\end{array}$ & \\
\hline 4 & $\begin{array}{l}\text { Episodic } \\
\text { Migraine }\end{array}$ & fremanezumab & $\begin{array}{l}\text { no preventive } \\
\text { treatment }\end{array}$ & $\$ 150,000$ & $\$ 110,000$ & $\mathrm{~N}$ & $-26.70 \%$ & Scenario & $\begin{array}{l}\text { Health } \\
\text { system }\end{array}$ & \\
\hline 5 & $\begin{array}{l}\text { Cystic Fibrosis } \\
\text { - Gaiting } \\
\text { \& Residual } \\
\text { Function } \\
\text { Mutations }\end{array}$ & ivacaftor & $\begin{array}{l}\text { best supportive } \\
\text { care }\end{array}$ & $\$ 956,762$ & $\$ 952,061$ & $\mathrm{~N}$ & $-0.50 \%$ & Scenario & $\begin{array}{l}\text { Health } \\
\text { system and } \\
\text { societal }\end{array}$ & $\begin{array}{l}\$ 50,000 / \text { QALY, } \\
\$ 100,000 / \text { QALY, } \\
\$ 150,000 / \text { QLY, } \\
\$ 200,000 / \text { QALY, } \\
\$ 300,000 / \text { QALY } \\
\text { and } \$ 500,000 / \\
\text { QALY }\end{array}$ \\
\hline 6 & $\begin{array}{l}\text { Cystic Fibrosis } \\
\text { - Homozygous } \\
\text { for F508del } \\
\text { Mutation }\end{array}$ & $\begin{array}{l}\text { lumacaftor/iva- } \\
\text { caftor }\end{array}$ & $\begin{array}{l}\text { best supportive } \\
\text { care }\end{array}$ & $\$ 890,739$ & $\$ 885,140$ & $\mathrm{~N}$ & $-0.60 \%$ & Scenario & $\begin{array}{l}\text { Health } \\
\text { system and } \\
\text { societal }\end{array}$ & \\
\hline 7 & $\begin{array}{l}\text { Cystic Fibrosis } \\
\text { - Homozygous } \\
\text { for F508del } \\
\text { Mutation }\end{array}$ & $\begin{array}{l}\text { texacaftor/iva- } \\
\text { caftor }\end{array}$ & $\begin{array}{l}\text { best supportive } \\
\text { care }\end{array}$ & $\$ 974,348$ & $\$ 968,744$ & $\mathrm{~N}$ & $-0.60 \%$ & Scenario & $\begin{array}{l}\text { Health } \\
\text { system and } \\
\text { societal }\end{array}$ & \\
\hline 8 & $\begin{array}{l}\text { Cystic Fibrosis } \\
\text { - Heterozygous } \\
\text { for F508del } \\
\text { Mutation }\end{array}$ & ivacaftor & $\begin{array}{l}\text { best supportive } \\
\text { care }\end{array}$ & $\$ 941,110$ & $\$ 936,633$ & $\mathrm{~N}$ & $-0.50 \%$ & Scenario & $\begin{array}{l}\text { Health } \\
\text { system and } \\
\text { societal }\end{array}$ & \\
\hline 9 & $\begin{array}{l}\text { Cystic Fibrosis } \\
\text { - Heterozygous } \\
\text { for F508del } \\
\text { Mutation }\end{array}$ & $\begin{array}{l}\text { texacaftor/iva- } \\
\text { caftor }\end{array}$ & $\begin{array}{l}\text { best supportive } \\
\text { care }\end{array}$ & $\$ 840,568$ & $\$ 835,987$ & $\mathrm{~N}$ & $-0.50 \%$ & Scenario & $\begin{array}{l}\text { Health } \\
\text { system and } \\
\text { societal }\end{array}$ & \\
\hline 10 & $\begin{array}{l}\text { Pediatric B-ALL } \\
\text { (Peds CAR-T) }\end{array}$ & tisagenlecleucel & chemotherapy & $\$ 45,871$ & $\$ 46,875$ & $\mathrm{~N}$ & $2.20 \%$ & Scenario & $\begin{array}{l}\text { Third-Party } \\
\text { Payer }\end{array}$ & $\begin{array}{l}\$ 50,000 / \text { QALY, } \\
\$ 100,000 / \text { QALY } \\
\text { and } \$ 150,000 / \\
\text { QALY }\end{array}$ \\
\hline 11 & $\begin{array}{l}\text { Adults with } \\
\text { NHL (Adult } \\
\text { CAR-T) }\end{array}$ & $\begin{array}{l}\text { axicabtagene } \\
\text { ciloleucel }\end{array}$ & chemotherapy & $\$ 136,078$ & $\$ 137,717$ & $\mathrm{~N}$ & $1.20 \%$ & Scenario & $\begin{array}{l}\text { Third-Party } \\
\text { payer }\end{array}$ & \\
\hline 12 & $\begin{array}{l}\text { Tardive } \\
\text { Dyskinesia }\end{array}$ & valbenazine & placebo & $\$ 752,080$ & $\$ 728,000$ & $\mathrm{~N}$ & $-3.20 \%$ & Scenario & $\begin{array}{l}\text { Health } \\
\text { System }\end{array}$ & $\begin{array}{l}\$ 50,000 / \text { QALY, } \\
\$ 100,000 / \text { QALY } \\
\text { and } \$ 150,000 / \\
\text { QALY }\end{array}$ \\
\hline 13 & \begin{tabular}{|l} 
Tardive \\
Dyskinesia
\end{tabular} & deutetrabenazine & placebo & $\$ 1,100,773$ & $\$ 1,077,000$ & $\mathrm{~N}$ & $-2.20 \%$ & Scenario & $\begin{array}{l}\text { Health } \\
\text { system }\end{array}$ & \\
\hline 14 & $\begin{array}{l}\text { Blindness - } 15 \\
\text { year olds }\end{array}$ & $\begin{array}{l}\text { voritegene } \\
\text { neparvovec }\end{array}$ & standard of care & $\$ 643,800$ & $\$ 480,100$ & $\mathrm{Y}$ & $-25.40 \%$ & $\begin{array}{l}\text { Co-base } \\
\text { case }\end{array}$ & $\begin{array}{l}\text { Health } \\
\text { System and } \\
\text { Societal }\end{array}$ & $\begin{array}{l}\$ 50,000 / \text { QALY, } \\
\$ 100,000 / \mathrm{QALY}, \\
\$ 150,000 / \mathrm{QALY} \\
\$ 250,000 / \mathrm{QALY} \\
\text { and } \$ 500,000 / \\
\text { QALY }\end{array}$ \\
\hline 15 & $\begin{array}{l}\text { Blindness - } 3 \\
\text { year olds }\end{array}$ & $\begin{array}{l}\text { voritegene } \\
\text { neparvovec }\end{array}$ & standard of care & $\$ 287,915$ & $\$ 135,331$ & $\mathrm{Y}$ & $-53.00 \%$ & $\begin{array}{l}\text { Co-base } \\
\text { case }\end{array}$ & $\begin{array}{l}\text { Health } \\
\text { system and } \\
\text { societal }\end{array}$ & \\
\hline
\end{tabular}


APPENDIX List of Treatment Comparisons Across All Reports (continued)

\begin{tabular}{|c|c|c|c|c|c|c|c|c|c|c|}
\hline \# & $\begin{array}{c}\text { Disease/ } \\
\text { Condition }\end{array}$ & $\begin{array}{c}\text { Drug/ } \\
\text { Intervention }\end{array}$ & Comparator & $\begin{array}{c}\text { Cost/QALY } \\
\text { (without } \\
\text { productivity) }\end{array}$ & $\begin{array}{c}\text { Cost/QALY } \\
\text { (with } \\
\text { productivity) }\end{array}$ & $\begin{array}{l}\text { Changes } \\
\text { ICER } \\
\text { Threshold } \\
\text { Category? }\end{array}$ & $\begin{array}{c}\% \\
\text { Change } \\
\end{array}$ & $\begin{array}{c}\text { Base Case } \\
\text { vs. } \\
\text { Scenario }\end{array}$ & $\begin{array}{c}\text { Model } \\
\text { Perspective }\end{array}$ & $\begin{array}{l}\text { ICER Thresholds } \\
\text { for Comparison }\end{array}$ \\
\hline 16 & Amyloidosis & inotersen & $\begin{array}{l}\text { best supportive } \\
\text { care }\end{array}$ & $\$ 1,730,000$ & $\$ 1,730,000$ & $\mathrm{~N}$ & $0.00 \%$ & $\begin{array}{l}\text { Co-base } \\
\text { case }\end{array}$ & $\begin{array}{l}\text { Health } \\
\text { system and } \\
\text { societal }\end{array}$ & $\begin{array}{l}\$ 50,000 / \text { QALY, } \\
\$ 100,000 / \text { QLY, } \\
\$ 150,000 / \text { QLY } \\
\text { and } \$ 500,000 / \\
\text { QALY }\end{array}$ \\
\hline 17 & Amyloidosis & patisiran & $\begin{array}{l}\text { best supportive } \\
\text { care }\end{array}$ & $\$ 835,000$ & $\$ 853,000$ & $\mathrm{~N}$ & $2.10 \%$ & $\begin{array}{l}\text { Co-base } \\
\text { case }\end{array}$ & $\begin{array}{l}\text { Health } \\
\text { system and } \\
\text { societal }\end{array}$ & \\
\hline 18 & Arthritis & rituximab & cDMARD & $\$ 198,056$ & $\$ 159,880$ & $\mathrm{~N}$ & $-23.80 \%$ & Scenario & $\begin{array}{l}\text { Health } \\
\text { System }\end{array}$ & $\begin{array}{l}\$ 50,000 / \text { QALY, } \\
\$ 100,000 / \text { QALY } \\
\text { and } \$ 150,000 / \\
\text { QALY }\end{array}$ \\
\hline 19 & Arthritis & abatacept (iv) & cDMARD & $\$ 191,317$ & $\$ 152,784$ & $\mathrm{~N}$ & $-25.20 \%$ & Scenario & $\begin{array}{l}\text { Health } \\
\text { System }\end{array}$ & \\
\hline 20 & Arthritis & abatacept (sc) & cDMARD & $\$ 225,853$ & $\$ 188,200$ & $\mathrm{~N}$ & $-20.00 \%$ & Scenario & $\begin{array}{l}\text { Health } \\
\text { System }\end{array}$ & \\
\hline 21 & Arthritis & tocilizumab (iv) & cDMARD & $\$ 183,949$ & $\$ 145,555$ & $\mathrm{Y}$ & $-26.30 \%$ & Scenario & $\begin{array}{l}\text { Health } \\
\text { System }\end{array}$ & \\
\hline 22 & Arthritis & tocilizumab (sc) & cDMARD & $\$ 168,660$ & $\$ 130,522$ & $\mathrm{Y}$ & $-29.20 \%$ & Scenario & $\begin{array}{l}\text { Health } \\
\text { System }\end{array}$ & \\
\hline 23 & Arthritis & tofacitinib & cDMARD & $\$ 271,749$ & $\$ 232,738$ & $\mathrm{~N}$ & $-16.70 \%$ & Scenario & $\begin{array}{l}\text { Health } \\
\text { System }\end{array}$ & \\
\hline 24 & Arthritis & adalimumab & cDMARD & $\$ 232,644$ & $\$ 193,763$ & $\mathrm{~N}$ & $-20.10 \%$ & Scenario & $\begin{array}{l}\text { Health } \\
\text { System }\end{array}$ & \\
\hline 25 & Arthritis & \begin{tabular}{|l} 
certolizumab \\
pegol
\end{tabular} & cDMARD & $\$ 209,736$ & $\$ 169,724$ & $\mathrm{~N}$ & $-23.50 \%$ & Scenario & $\begin{array}{l}\text { Health } \\
\text { System }\end{array}$ & \\
\hline 26 & Arthritis & etanercept & cDMARD & $\$ 212,021$ & $\$ 173,345$ & $\mathrm{~N}$ & $-22.30 \%$ & Scenario & $\begin{array}{l}\text { Health } \\
\text { System }\end{array}$ & \\
\hline 27 & Arthritis & golimumab (sc) & CDMARD & $\$ 222,380$ & $\$ 183,025$ & $\mathrm{~N}$ & $-21.50 \%$ & Scenario & $\begin{array}{l}\text { Health } \\
\text { System }\end{array}$ & \\
\hline 28 & Arthritis & golimumab (iv) & cDMARD & $\$ 204,212$ & $\$ 165,380$ & $\mathrm{~N}$ & $-23.40 \%$ & Scenario & $\begin{array}{l}\text { Health } \\
\text { System }\end{array}$ & \\
\hline 29 & Arthritis & infliximab & CDMARD & $\$ 202,824$ & $\$ 164,194$ & $\mathrm{~N}$ & $-23.50 \%$ & Scenario & $\begin{array}{l}\text { Health } \\
\text { System }\end{array}$ & \\
\hline 30 & Arthritis & rituximab & adalimumab & \begin{tabular}{|l|} 
Less costly, \\
more effective
\end{tabular} & \begin{tabular}{|l|} 
Less costly, \\
more effective
\end{tabular} & $\mathrm{N}$ & N/A & Scenario & $\begin{array}{l}\text { Health } \\
\text { System }\end{array}$ & \\
\hline 31 & Arthritis & abatacept (iv) & adalimumab & \begin{tabular}{|l|} 
Less costly, \\
more effective
\end{tabular} & \begin{tabular}{|l|} 
Less costly, \\
more effective
\end{tabular} & $\mathrm{N}$ & N/A & Scenario & $\begin{array}{l}\text { Health } \\
\text { System }\end{array}$ & \\
\hline 32 & Arthritis & abatacept (sc) & adalimumab & $\$ 163,376$ & $\$ 137,017$ & Y & $-19.20 \%$ & Scenario & $\begin{array}{l}\text { Health } \\
\text { System }\end{array}$ & \\
\hline 33 & Arthritis & tocilizumab (iv) & adalimumab & \begin{tabular}{|l|} 
Less costly, \\
more effective
\end{tabular} & \begin{tabular}{|l|} 
Less costly, \\
more effective
\end{tabular} & $\mathrm{N}$ & N/A & Scenario & $\begin{array}{l}\text { Health } \\
\text { System }\end{array}$ & \\
\hline 34 & Arthritis & tocilizumab (sc) & adalimumab & \begin{tabular}{|l|} 
Less costly, \\
more effective
\end{tabular} & \begin{tabular}{|l|} 
Less costly, \\
more effective
\end{tabular} & $\mathrm{N}$ & N/A & Scenario & $\begin{array}{l}\text { Health } \\
\text { System }\end{array}$ & \\
\hline 35 & Arthritis & tofacitinib & adalimumab & $\begin{array}{l}\text { More costly, } \\
\text { less effective }\end{array}$ & $\begin{array}{l}\text { More costly, } \\
\text { less effective }\end{array}$ & $\mathrm{N}$ & N/A & Scenario & $\begin{array}{l}\text { Health } \\
\text { System }\end{array}$ & \\
\hline 36 & Arthritis & $\begin{array}{l}\text { certolizumab } \\
\text { pegol }\end{array}$ & adalimumab & \begin{tabular}{|l|} 
Less costly, \\
more effective
\end{tabular} & \begin{tabular}{|l|} 
Less costly, \\
more effective
\end{tabular} & $\mathrm{N}$ & N/A & Scenario & $\begin{array}{l}\text { Health } \\
\text { System }\end{array}$ & \\
\hline 37 & Arthritis & etanercept & adalimumab & $\$ 119,233$ & $\$ 81,481$ & Y & $-46.30 \%$ & Scenario & $\begin{array}{l}\text { Health } \\
\text { System }\end{array}$ & \\
\hline 38 & Arthritis & golimumab (sc) & adalimumab & \begin{tabular}{|l|} 
Less costly, \\
more effective
\end{tabular} & \begin{tabular}{|l|} 
Less costly, \\
more effective
\end{tabular} & $\mathrm{N}$ & N/A & Scenario & $\begin{array}{l}\text { Health } \\
\text { System }\end{array}$ & \\
\hline 39 & Arthritis & golimumab (iv) & adalimumab & \begin{tabular}{|l|} 
Less costly, \\
more effective
\end{tabular} & \begin{tabular}{|l|} 
Less costly, \\
more effective
\end{tabular} & $\mathrm{N}$ & N/A & Scenario & $\begin{array}{l}\text { Health } \\
\text { System }\end{array}$ & \\
\hline 40 & Arthritis & infliximab & adalimumab & $\begin{array}{l}\text { Less costly, } \\
\text { more effective }\end{array}$ & \begin{tabular}{|l|} 
Less costly, \\
more effective
\end{tabular} & $\mathrm{N}$ & N/A & Scenario & $\begin{array}{l}\text { Health } \\
\text { System }\end{array}$ & \\
\hline
\end{tabular}


APPENDIX List of Treatment Comparisons Across All Reports (continued)

\begin{tabular}{|c|c|c|c|c|c|c|c|c|c|c|}
\hline \# & $\begin{array}{l}\text { Disease/ } \\
\text { Condition }\end{array}$ & $\begin{array}{c}\text { Drug/ } \\
\text { Intervention }\end{array}$ & Comparator & $\begin{array}{c}\text { Cost/QALY } \\
\text { (without } \\
\text { productivity) }\end{array}$ & $\begin{array}{c}\text { Cost/QALY } \\
\text { (with } \\
\text { productivity) }\end{array}$ & $\begin{array}{l}\text { Changes } \\
\text { ICER } \\
\text { Threshold } \\
\text { Category? } \\
\end{array}$ & $\begin{array}{c}\% \\
\text { Change }\end{array}$ & $\begin{array}{c}\text { Base Case } \\
\text { vs. } \\
\text { Scenario } \\
\end{array}$ & $\begin{array}{c}\text { Model } \\
\text { Perspective }\end{array}$ & $\begin{array}{l}\text { ICER Thresholds } \\
\text { for Comparison }\end{array}$ \\
\hline 41 & Prostate Cancer & $\begin{array}{l}\text { apalutamide + } \\
\text { ADT }\end{array}$ & continued ADT & $\$ 67,924$ & $\$ 67,924$ & $\mathrm{~N}$ & $0.00 \%$ & Scenario & $\begin{array}{l}\text { Health } \\
\text { Sector }\end{array}$ & $\begin{array}{l}\$ 50,000 / \text { QALY, } \\
\$ 100,000 / \text { QALY } \\
\text { and } \$ 150,000 / \\
\text { QALY }\end{array}$ \\
\hline 42 & Prostate Cancer & $\begin{array}{l}\text { enzalutamide + } \\
\text { ADT }\end{array}$ & continued ADT & $\$ 84,000$ & $\$ 83,333$ & $\mathrm{~N}$ & $-0.80 \%$ & Scenario & $\begin{array}{l}\text { Health } \\
\text { Sector }\end{array}$ & \\
\hline 43 & Psoriasis & adalimumab & $\begin{array}{l}\text { non-targeted } \\
\text { treatment }\end{array}$ & $\$ 164,000$ & $\$ 141,000$ & $\mathrm{Y}$ & $-16.30 \%$ & Scenario & $\begin{array}{l}\text { Health } \\
\text { Sector }\end{array}$ & $\begin{array}{l}\$ 50,000 / \text { QALY, } \\
\$ 100,000 / \text { QALY } \\
\text { and } \$ 150,000 / \\
\text { QALY }\end{array}$ \\
\hline 44 & Psoriasis & apremilast & $\begin{array}{l}\text { non-targeted } \\
\text { treatment }\end{array}$ & $\$ 135,000$ & $\$ 111,000$ & $\mathrm{~N}$ & $-21.60 \%$ & Scenario & $\begin{array}{l}\text { Health } \\
\text { Sector }\end{array}$ & \\
\hline 45 & Psoriasis & brodalumab & $\begin{array}{l}\text { non-targeted } \\
\text { treatment }\end{array}$ & $\$ 131,000$ & $\$ 109,000$ & $\mathrm{~N}$ & $-20.20 \%$ & Scenario & $\begin{array}{l}\text { Health } \\
\text { Sector }\end{array}$ & \\
\hline 46 & Psoriasis & \begin{tabular}{|l} 
certolizumab \\
pegol
\end{tabular} & $\begin{array}{l}\text { non-targeted } \\
\text { treatment }\end{array}$ & $\$ 188,000$ & $\$ 165,000$ & $\mathrm{~N}$ & $-13.90 \%$ & Scenario & $\begin{array}{l}\text { Health } \\
\text { Sector }\end{array}$ & \\
\hline 47 & Psoriasis & etanercept & $\begin{array}{l}\text { non-targeted } \\
\text { treatment }\end{array}$ & $\$ 175,000$ & $\$ 151,000$ & $\mathrm{~N}$ & $-15.80 \%$ & Scenario & $\begin{array}{l}\text { Health } \\
\text { Sector }\end{array}$ & \\
\hline 48 & Psoriasis & guselkumab & $\begin{array}{l}\text { non-targeted } \\
\text { treatment }\end{array}$ & $\$ 161,000$ & $\$ 139,000$ & $\mathrm{Y}$ & $-15.80 \%$ & Scenario & $\begin{array}{l}\text { Health } \\
\text { Sector }\end{array}$ & \\
\hline 49 & Psoriasis & infliximab & $\begin{array}{l}\text { non-targeted } \\
\text { treatment }\end{array}$ & $\$ 134,000$ & $\$ 111,000$ & $\mathrm{~N}$ & $-20.70 \%$ & Scenario & $\begin{array}{l}\text { Health } \\
\text { Sector }\end{array}$ & \\
\hline 50 & Psoriasis & ixekizumab & $\begin{array}{l}\text { non-targeted } \\
\text { treatment }\end{array}$ & $\$ 142,000$ & $\$ 120,000$ & $\mathrm{~N}$ & $-18.30 \%$ & Scenario & $\begin{array}{l}\text { Health } \\
\text { Sector }\end{array}$ & \\
\hline 51 & Psoriasis & secukinumab & $\begin{array}{l}\text { non-targeted } \\
\text { treatment }\end{array}$ & $\$ 145,000$ & $\$ 123,000$ & $\mathrm{~N}$ & $-17.80 \%$ & Scenario & $\begin{array}{l}\text { Health } \\
\text { Sector }\end{array}$ & \\
\hline 52 & Psoriasis & ustekinumab & $\begin{array}{l}\text { non-targeted } \\
\text { treatment }\end{array}$ & $\$ 169,000$ & $\$ 146,000$ & $\mathrm{Y}$ & $-15.70 \%$ & Scenario & $\begin{array}{l}\text { Health } \\
\text { Sector }\end{array}$ & \\
\hline 53 & Endometriosis & $\begin{array}{l}\text { elagolix } 200 \\
\text { mg twice daily } \\
\text { (long-run) }\end{array}$ & $\begin{array}{l}\text { no active treat- } \\
\text { ment }\end{array}$ & $\$ 81,000$ & $\$ 48,900$ & $\mathrm{Y}$ & $-65.60 \%$ & Scenario & $\begin{array}{l}\text { Health } \\
\text { Sector }\end{array}$ & \\
\hline 54 & $\begin{array}{l}\text { Hemophilia A } \\
\text { in }>12 \text { years } \\
\text { old }\end{array}$ & emicizumab & no prophylaxis & $\begin{array}{l}\text { Less costly, } \\
\text { more effective }\end{array}$ & $\begin{array}{l}\text { Less costly, } \\
\text { more effective }\end{array}$ & $\mathrm{N}$ & N/A & Scenario & $\begin{array}{l}\text { Health } \\
\text { Sector }\end{array}$ & \\
\hline 55 & $\begin{array}{l}\text { Hemophilia A } \\
\text { in > } 12 \text { years } \\
\text { old }\end{array}$ & emicizumab & BPA prophylaxis & $\begin{array}{l}\text { Less costly, } \\
\text { more effective }\end{array}$ & $\begin{array}{l}\text { Less costly, } \\
\text { more effective }\end{array}$ & $\mathrm{N}$ & N/A & Scenario & $\begin{array}{l}\text { Health } \\
\text { Sector }\end{array}$ & \\
\hline 56 & $\begin{array}{l}\text { Hemophilia A } \\
\text { in }<12 \text { years } \\
\text { old }\end{array}$ & emicizumab & no prophylaxis & \begin{tabular}{|l|} 
Less costly, \\
more effective
\end{tabular} & \begin{tabular}{|l|} 
Less costly, \\
more effective
\end{tabular} & $\mathrm{N}$ & N/A & Scenario & $\begin{array}{l}\text { Health } \\
\text { Sector }\end{array}$ & \\
\hline 57 & $\begin{array}{l}\text { Hemophilia A } \\
\text { in <12 years } \\
\text { old }\end{array}$ & emicizumab & BPS prophylaxis & \begin{tabular}{|l|} 
Less costly, \\
more effective
\end{tabular} & \begin{tabular}{|l|} 
Less costly, \\
more effective
\end{tabular} & $\mathrm{N}$ & N/A & Scenario & $\begin{array}{l}\text { Health } \\
\text { Sector }\end{array}$ & \\
\hline 58 & Asthma & omalizumab & Standard of care & $\$ 325,000$ & $\$ 303,000$ & $\mathrm{~N}$ & $-7.26 \%$ & Scenario & $\begin{array}{l}\text { Health } \\
\text { Sector }\end{array}$ & $\begin{array}{l}\$ 50,000 / \text { QALY, } \\
\$ 100,000 / \text { QALY } \\
\text { and } \$ 150,000 / \\
\text { QALY }\end{array}$ \\
\hline 59 & Asthma & mepolizumab & Standard of Care & $\$ 344,000$ & $\$ 320,000$ & $\mathrm{~N}$ & $-7.50 \%$ & Scenario & $\begin{array}{l}\text { Health } \\
\text { Sector }\end{array}$ & \\
\hline 60 & Asthma & reslizumab & Standard of Care & $\$ 391,000$ & $\$ 364,000$ & $\mathrm{~N}$ & $-7.42 \%$ & Scenario & $\begin{array}{l}\text { Health } \\
\text { Sector }\end{array}$ & \\
\hline 61 & Asthma & benralizumab & Standard of Care & $\$ 371,000$ & $\$ 342,000$ & $\mathrm{~N}$ & $-8.48 \%$ & Scenario & $\begin{array}{l}\text { Health } \\
\text { Sector }\end{array}$ & \\
\hline 62 & Asthma & dupilumab & Standard of Care & $\$ 351,000$ & $\$ 327,000$ & $\mathrm{~N}$ & $-7.34 \%$ & Scenario & $\begin{array}{l}\text { Health } \\
\text { Sector }\end{array}$ & \\
\hline
\end{tabular}




\section{APPENDIX List of Treatment Comparisons Across All Reports (continued)}

\begin{tabular}{|c|c|c|c|c|c|c|c|c|c|c|}
\hline \# & $\begin{array}{l}\text { Disease/ } \\
\text { Condition }\end{array}$ & $\begin{array}{c}\text { Drug/ } \\
\text { Intervention }\end{array}$ & Comparator & $\begin{array}{l}\text { Cost/QALY } \\
\text { (without } \\
\text { productivity) }\end{array}$ & $\begin{array}{c}\text { Cost/QALY } \\
\text { (with } \\
\text { productivity) }\end{array}$ & \begin{tabular}{|l|} 
Changes \\
ICER \\
Threshold \\
Category?
\end{tabular} & $\begin{array}{c}\% \\
\text { Change }\end{array}$ & $\begin{array}{c}\text { Base Case } \\
\text { vs. } \\
\text { Scenario }\end{array}$ & $\begin{array}{c}\text { Model } \\
\text { Perspective }\end{array}$ & $\begin{array}{l}\text { ICER Thresholds } \\
\text { for Comparison }\end{array}$ \\
\hline 63 & $\begin{array}{l}\text { Hereditary } \\
\text { Angioedema }\end{array}$ & Cinryze & No Prophylaxis & $\$ 5,954,000$ & $\$ 4,367,000$ & $\mathrm{~N}$ & $-36.34 \%$ & Scenario & $\begin{array}{l}\text { Health } \\
\text { Sector }\end{array}$ & $\begin{array}{l}\$ 50,000 / \mathrm{QALY} \\
\$ 100,000 / \mathrm{Q} A L Y \\
\$ 150,000 / \mathrm{Q} A L Y \\
\$ 250,000 / \mathrm{QALY} \\
\text { and } \$ 500,000 / \\
\text { QALY }\end{array}$ \\
\hline 64 & $\begin{array}{l}\text { Hereditary } \\
\text { Angioedema }\end{array}$ & Haegarda & No Prophylaxis & $\$ 328,000$ & $\$ 257,000$ & $\mathrm{~N}$ & $-27.63 \%$ & Scenario & $\begin{array}{l}\text { Health } \\
\text { Sector }\end{array}$ & \\
\hline 65 & $\begin{array}{l}\text { Hereditary } \\
\text { Angioedema }\end{array}$ & Lanadelumab & No Prophylaxis & $\$ 1,108,000$ & $\$ 1,189,000$ & $\mathrm{~N}$ & $6.81 \%$ & Scenario & $\begin{array}{l}\text { Health } \\
\text { Sector }\end{array}$ & \\
\hline 66 & $\begin{array}{l}\text { Opioid Use } \\
\text { Disorder }\end{array}$ & Vivitrol & $\begin{array}{l}\text { Generic SL } \\
\text { Buprenorphine/ } \\
\text { Naloxone) }\end{array}$ & $\begin{array}{l}\text { More costly, } \\
\text { less effective }\end{array}$ & $\begin{array}{l}\text { More costly, } \\
\text { less effective }\end{array}$ & $\mathrm{N}$ & N/A & Scenario & $\begin{array}{l}\text { Health } \\
\text { Sector }\end{array}$ & $\begin{array}{l}\$ 50,000 / \text { QALY, } \\
\$ 100,000 / \text { QALY } \\
\text { and } \$ 150,000 / \\
\text { QALY }\end{array}$ \\
\hline 67 & $\begin{array}{l}\text { Opioid Use } \\
\text { Disorder }\end{array}$ & Probuphine & $\begin{array}{l}\text { Generic SL } \\
\text { Buprenorphine/ } \\
\text { Naloxone) }\end{array}$ & $\$ 265,000$ & $\begin{array}{l}\text { less costly, } \\
\text { more effective }\end{array}$ & $\mathrm{Y}$ & N/A & Scenario & $\begin{array}{l}\text { Health } \\
\text { Sector }\end{array}$ & \\
\hline 68 & $\begin{array}{l}\text { Spinal } \\
\text { Muscular } \\
\text { Atrophy }\end{array}$ & Spinraza & $\begin{array}{l}\text { Best supportive } \\
\text { care }\end{array}$ & $\$ 1,112,000$ & $\$ 1,124,000$ & $\mathrm{~N}$ & $1.08 \%$ & Scenario & $\begin{array}{l}\text { Health } \\
\text { Sector }\end{array}$ & $\begin{array}{l}\$ 50,000 / \mathrm{QALY} \\
\$ 100,000 / \mathrm{QALY} \\
\$ 150,000 / \mathrm{QALY} \\
\$ 200,000 / \mathrm{Q} A L Y \\
\$ 300,000 / \mathrm{QALY} \\
\text { and } \$ 500,000 / \\
\text { QALY }\end{array}$ \\
\hline 69 & $\begin{array}{l}\text { Spinal } \\
\text { Muscular } \\
\text { Atrophy } \\
\end{array}$ & Zolgensma & $\begin{array}{l}\text { Best supportive } \\
\text { Care }\end{array}$ & $\$ 243,000$ & $\$ 238,000$ & $\mathrm{~N}$ & $-2.06 \%$ & Scenario & $\begin{array}{l}\text { Health } \\
\text { Sector }\end{array}$ & \\
\hline 70 & Peanut Allergy & $\begin{array}{l}\text { AR101 oral } \\
\text { immunotherapy } \\
+ \text { avoidance }\end{array}$ & Avoidance & $\$ 88,000$ & $\$ 27,000$ & $\mathrm{Y}$ & $-69.32 \%$ & Scenario & $\begin{array}{l}\text { Health } \\
\text { Sector }\end{array}$ & $\begin{array}{l}\$ 50,000 / \text { QALY, } \\
\$ 100,000 / \text { QALY } \\
\text { and } \$ 150,000 / \\
\text { QALY }\end{array}$ \\
\hline 71 & Peanut Allergy & $\begin{array}{l}\text { Viaskin Peanut + } \\
\text { avoidance }\end{array}$ & Avoidance & $\$ 216,000$ & $\$ 155,000$ & $\mathrm{~N}$ & $-28.24 \%$ & Scenario & $\begin{array}{l}\text { Health } \\
\text { Sector }\end{array}$ & \\
\hline 72 & Peanut Allergy & $\begin{array}{l}\text { AR101 oral } \\
\text { immunotherapy } \\
+ \text { avoidance }\end{array}$ & Avoidance & $\$ 88,000$ & $\begin{array}{l}\text { Range } \\
\$ 24,500 \text { - } \\
\$ 17,500\end{array}$ & $\mathrm{Y}$ & $\begin{array}{l}(-72.1 \% \text { to } \\
-80.1 \%)\end{array}$ & Scenario & $\begin{array}{l}\text { Health } \\
\text { Sector }\end{array}$ & \\
\hline 73 & Peanut Allergy & $\begin{array}{l}\text { Viaskin Peanut + } \\
\text { avoidance }\end{array}$ & Avoidance & $\$ 216,000$ & $\begin{array}{l}\text { Range } \\
\$ 140,000- \\
\$ 100,000\end{array}$ & $\mathrm{Y}$ & $\begin{array}{l}(-35.1 \% \text { to } \\
-53.7 \%)\end{array}$ & Scenario & $\begin{array}{l}\text { Health } \\
\text { Sector }\end{array}$ & \\
\hline 74 & $\begin{array}{l}\text { Multiple } \\
\text { Sclerosis } \\
\text { (Overall SPMS } \\
\text { population) }\end{array}$ & Siponimod & $\begin{array}{l}\text { Best supportive } \\
\text { care }\end{array}$ & $\$ 1,150,000$ & $\$ 1,140,000$ & $\mathrm{~N}$ & $-0.87 \%$ & Scenario & $\begin{array}{l}\text { Health } \\
\text { Sector }\end{array}$ & $\begin{array}{l}\$ 50,000 / \text { QALY, } \\
\$ 100,000 / \text { QALY } \\
\text { and } \$ 150,000 / \\
\text { QALY }\end{array}$ \\
\hline 75 & $\begin{array}{l}\text { Treatment- } \\
\text { Resistant } \\
\text { Depression }\end{array}$ & $\begin{array}{l}\text { Esketamine } \\
\text { nasal spray + } \\
\text { background } \\
\text { antidepressant }\end{array}$ & $\begin{array}{l}\text { Background anti- } \\
\text { depressant alone }\end{array}$ & $\$ 198,000$ & $\$ 188,000$ & $\mathrm{~N}$ & $-5.05 \%$ & Scenario & $\begin{array}{l}\text { Health } \\
\text { Sector }\end{array}$ & $\begin{array}{l}\$ 50,000 / \text { QALY, } \\
\$ 100,000 / \text { QALY } \\
\text { and } \$ 150,000 / \\
\text { QALY }\end{array}$ \\
\hline
\end{tabular}

$A D T=$ androgen deprivation therapy; $B-A L L=B$-cell acute lymphoblastic leukemia; $B P A=b i s p h e n o l ~ A ; B P S=b e s t$ practice statement; $c D M A R D=c o n v e n t i o n a l ~ d i s e a s e-$ modifying antirheumatic drugs; ICER=incremental cost-effectiveness ratio; iv=intravenous; NHL=non-Hodgkin leukemia; QALY=quality-adjusted life-year; sc = subcutaneous. 